\title{
Birthe Paul
}

Germany

University of Maastricht

\section{Eurocentrism - A Hidden, but Hot Topic}

\section{The Roots of Eurocentrism}

The notion of Eurocentrism emerged in the times of European imperialism in the 16th, 17th and 18th century and is defined as a conscious as well as unconscious emphasis on Western or European culture, values and concerns standing above others. In other words, it is the mental attitude to perceive non-Europeans or today non-Westerners as less modern, less civilized, less relevant and just less than equal. This historic notion is very much connected to Edward Said, who marked the concept of Orientalism and its connection to a Eurocentric worldview.

According to him, Eurocentrism lies at the heart of European culture due to the many decades of imperial expansion. It studied and subordinated other cultures to the very idea of the white Christian Europe, which were considered to be naturally subservient to a superior, advanced, developed and morally mature Europe. From this racist point of view, not only slavery, but genocides and other exploitation were justified in the past. The Third World was vicious and weak and had to be 'civilized'. The Western technological and economic superiority put them automatically in a perceived higher position.

\section{Eurocentrism Today}

Nevertheless, Eurocentrism is not only an issue of the past, but in fact, this angle of European superiority can still be observed today. Eurocentrism is involved into so much more aspects of daily life and so much more acute than we anticipate on first sight. Unfortunately, it is not an outdated concept slowly but completely disappearing in a ever closer global world nowadays, but a real hot and neglected topic. Although many people may perceive themselves to be open-minded and not racist, a eurocentric worldview is actually hard to avoid because it is hidden in a lot of public discourses, often accelerated through the mass media.

\section{Invention of Western Tradition}

The Western interpretation of world history is only one example, which mostly sheds light on the insights of philosophers such as Aristotle, Kant or Marx or stressing the discoveries of Newton and Leibnitz. Europe is presented as being central in preparing the explosion of science and technology and economic development while the achievements of Confucius, 
Gandhi and the early findings of Indian, Chinese and Islamic scientists are neglected. This phenomenon became to be called 'invention of tradition', and this one-sided view is given further at today's schools and universities. Eurocentrism is not only present in the historical education, but as well in mathematics or arts. In this way, common identity is constructed by choosing and stressing particular glorious moments in history.

\section{Clash of Civilizations: Islam vs. Christianity}

Another example is the current public discussion on the 'Clash of Civilizations', which once was initiated by Samuel Huntington. A core claim of Huntington is that Western concepts differ fundamentally from those prevalent in other civilizations. Ideas like liberalism, human rights, equality, liberty, rule of law, democracy, secularism, constitutionalism and individualism are Western principles which only find little resonance in Islamic, Japanese, Hindu, Buddhist, Orthodox or Confucian cultures, if we believe Huntington. This indeed reflects a deeply Eurocentric worldview: But are all these values really Western? And do other cultures not have their own versions of democracy? Since other cultures or groups can never fully conform to the criteria defined by Huntington, his theory tends to imply a biased judgment about 'good' and 'bad', a superiority of one 'civilized' culture above the other, as included as well in the definition from the beginning. However, the expression of a 'Clash of Civilizations' has proven to be very popular in the current public discussions on terrorism or confrontations due to the Mohammed cartoons published in a Danish newspaper. The conflict of Christian and Islamic culture sometimes appears to be unavoidable in Western newspapers due to long inherited differences between both. In presenting the problems in such a way, the issue is only considered from a European point of view. The Islamic culture is presented as not allowing freedom of speech and opinion and anyways not fulfilling at all human rights standards. The Western culture arises as being enlightened and superior in reaching a high level of human rights and freedoms which 'the others' unfortunately do not enjoy.

However, it is obvious that the entire problem cannot be solved if both sides stay within these borders of thinking. This limited viewpoint avoids dialogue and ignores possibilities to learn from each other. Instead, only international thinking could be a solution, so trying so see the same issue from different angles and using the power of empathy. Both sides should try to get rid of the self-invented images of the other side, but instead deal with the other side in an openminded way. Value systems are always highly complex, difficult and often contradictory and cannot be described with a simple list of stereotypes. When taking this into account, a Eurocentric approach, which is a comparison of lists of characteristics of for example blacks, Arabs, Chinese and Europeans in order to make a ranking, can be successfully avoided. 


\section{Fortress Europe: Exclusion of 'The Others'}

There is as well a relation between Eurocentrism and the policing of the EU external borders, which is already described as 'Fortress Europe'. Since the opening of internal borders within the European Union and the abolition of border controls, the EU external borders are more closed and secured than ever. This became known as the border paradox: The more the internal borders are disappearing, the stronger and more inspected the external ones get. The separation of European insiders and outsiders has grown far more rigid and clear and access for $3^{\text {rd }}$ country nationals is mostly denied at the high-tech borders. Yet, the scenarios are becoming more and more alarming and serious. Hundreds and thousands of desperate refugees try to enter the prosperous continent, and it even begins to resemble situations of invasion. On the other hand, it has become increasingly difficult to enter the EU with the increased security at the external borders. This is why the metaphor of a 'Fortress Europe' has become popular in the discourse on EU Migration Policy. There could not be any better and more revealing picture for symbolizing Eurocentrism today. Europe appears as a closed-up community not willing get in contact with outsiders and even keeping them out with physical violence. A notion of superiority is obviously implied. The entire discourse on for example Ceuta and Melilla do not really evolve around the real interests and concerns of the refugees, but are still foremost about how to secure the external borders without too much violating human rights standards.

All in all, we can see that Eurocentrism lies at the heart of a European identity building. People always need to define an own identity by contrasting themselves to 'the others'. The other culture is only used to fabricate a positive self-image. Although this mechanism may seem very wrong, it is still understandable. It basically fosters the feeling of belonging together and solidarity. Nevertheless, this human process should be carefully watched and kept within certain borders. A healthy compromise has to be found between self-definition and openness to 'otherness'.

\section{Conclusion}

What conclusions to draw from this? As seen in these three examples, Eurocentrism is more present in our daily lives and in our heads than we may expect. It is important to keep the own perspective and forming in mind. Probably, no European can completely absolve from any unconscious Eurocentric views due to the growing up in a certain environment which of course has left its marks. Why was the whole world shocked and deeply moved by pictures from 09-11 and the attack on innocent white men like you and me, while the much bigger suffering in Africa does not trigger any comparable reactions? And why do news reports when reporting on catastrophes far away still first mention the victims of own nationality and then reporting on the 
entire scope of the disaster? If everybody is well aware of these sleeping attitudes instead of totally denying any existence, then the European society is ready to overcome the most extreme outcomes and reach a satisfactory degree of international thinking. The civil society has to become more critical and conscious about the own point of view. International thinking can be learnt and acquired; we just have to start living it ourselves. 